\title{
Study on the Path of Ideological and Political Education in Tax Departments in the New Period
}

\author{
Yong Tan \\ Yinxing Hospitality Management College of CUIT, Chengdu 611743, China. \\ 852733094@qq.com
}

\begin{abstract}
Since entering the new period of socialism with Chinese characteristics, the duties and phased objectives of the tax department have also been adjusted and optimized accordingly, in which the path and mode of ideological and political education should be improved. Based on the experience of ideological and political education with Chinese characteristics and the theoretical achievements of the party and the state in the new period, this paper focuses on clarifying the relationship between ideological and political education and the effectiveness of tax departments, highlighting the complementary and beneficial relationship between the two. Further sort out the tax department in the new era and new background to carry out ideological and political education work path.
\end{abstract}

Keywords: New period; Tax department; Ideological and political education; work Path Research.

\section{Introduction}

Since the 19th CPC National Congress, all kinds of reform work in China have gone hand in hand, further clarifying the grand blueprint for a well-off society in an all-round way. As the actual grasp of China's financial work, the tax department has focused on the work in the past. Relatively neglecting the grasp of moral education and the rule of law education, deepening the reform of tax departments has adapted to the needs of the further development of productive forces, and as a reform in the field of superstructure, it can play a counter-effect on the promotion of productive forces. More in line with the rapid changes in the social structure of the adjustment needs.

Under the background of the new period, the responsibilities and phased objectives of the tax department have also been adjusted and optimized accordingly. In the report of the 19th CPC National Congress, it is pointed out that it is necessary to integrate personnel and departments in order to highlight the integration of tax work and solve the problem of "multiplication" and fragmentation of tax work at the new historical stage. Take the forerunner of thought as the leading role of integration. The way and consciousness of tax payment service need to be further strengthened. in recent years, more and more people have been praised for their satisfactory service innovation, and its inherent logic is to closely follow the guidance of the central supply-side structural reform. Focus on the multi-level needs of taxpayers, in order to meet the demand as the main purpose. However, there are still some problems, such as the lack of active service consciousness, the low quality of cadres and the impetuous work style. In view of this series of problems, it is urgent to grasp the ideological style and improve the quality of work. Among them, the path and way of carrying out ideological and political education should be improved with the development of ideological and political education. How to combine the new stage characteristics more reasonable and more effective in the tax department to carry out ideological and political education is the focus of this paper.

\section{The Complementary and Beneficial Relationship between Ideological and Political Education and the Work Effectiveness of Tax Departments}

This paper holds that there is a complementary and beneficial relationship between ideological and political education and the work effectiveness of tax departments, which is not only based on the scientific perspective of dialectics, but also a summary of the experience in practical work. Complementary gain means that there is a strong positive correlation between the ideological and political education and the duty work of the tax department, that is to say, the development of the 
ideological and political education can improve the actual work effect of the tax department. The progress of the work of the tax department can also create better conditions for the development of ideological and political education. As a powerful tool of ideology, ideological and political education is realized by the reaction of consciousness to material in the process of carrying out the work of tax departments, mainly the education and integration of individual consciousness.

From the impact of ideological and political education on the effectiveness of tax departments. First, ideological and political education can correct the attitude of the staff of the tax department, and the personal attitude is through the process of practical contact, and combined with continuous acquired learning to form a more stable understanding and judgment of specific things. It belongs to the category of value judgment. Ideological and political education can achieve the change of attitude through the transformation of motivation, the stimulation of interests and the correction of behavior. Second, the attitude touches the engine, the motivation causes the behavior, the correct work attitude can promote the tax department staff to work actively, handle affairs in a down-to-earth manner, and the scientific work attitude can speed up the scientific adjustment of the organizational structure; The democratic deliberative attitude can establish the improvement of the internal communication mechanism of the tax department and the change of the way of communication with the masses, and then contribute to the smooth development of the work of the department.

From the perspective of the influence of the tax department on the ideological and political education work, the accumulation of the work of the tax department has laid a solid material foundation and spiritual demand for the development of ideological and political education. First, there is only lasting and unremitting work. In order to continue to accumulate departmental work experience, in order to create conditions for the enrichment of spiritual activities; The second is that the continuity of the work will constantly stimulate the demand for the spiritual activities of ideological and political education, and realize the continuous encouragement and mobilization through the way of consciousness and culture.

\section{The Ways to Carry out the Ideological and Political Education of Tax Departments in the New Period}

The connotation of ideological and political education determines that it is a powerful tool for the development of ideological and political work. The transformation of the working mode of national and local tax cadres, the reversal of ideology and the improvement of their attitude all depend on the development of ideological and political education. Give full play to the reaction of consciousness to matter. Some scholars believe that at present, the tax authorities are facing greater contradictions at the level of handling grass-roots affairs, mainly manifested in heavy affairs, dissatisfaction among the masses, and pressure from superiors, and that they do not pay enough attention to the work of ideological and political education. More affected by the previous governments at all levels of our country "only GDP" assessment standards, ignoring the importance of ideological and political education. In fact, as the ideological leader of all kinds of work, ideological and political work is not of key significance. It can give strong guidance to all kinds of work in epistemology and methodology, and the lack of attention has brought about problems in several aspects. The core position of ideological and political education work has been lost, and the integration role of educational work has not been brought into full play and the passive situation of its status.

\subsection{Strengthening the Ideological and Political Guidance in the Content of Business}

Professional training to increase the number of ideological and political education courses. At the beginning of the training, in the process of staff entry, on the one hand, new ideological and political education courses are set up, and on the other hand, in order to cultivate ideological and moral character, serious and responsible work attitude and handling style, Second, in order to subconsciously improve the degree of attention to ideological and political education work, only the attention of the individual to enhance, the overall degree of attention can be further improved. Secondly, strengthen the relationship with policy. The policy relevance is to both match up and take 
it down. The above refers to the contents and tasks of ideological and political education work distributed and guided by the party committees and governments at higher levels, and next to the problems actually reflected by the masses in the light of the actual work situation in the local areas and the actual problems reflected by the masses at all levels of the local tax departments in important countries. Targeted combined with particularity to carry out ideological and political education work, to avoid "one size fits all" and "one grasp". Finally, we should strengthen the pertinence of the content of ideological and political education. One of the basic factors affecting the effectiveness of ideological and political education for grass-roots tax officials is the selection of educational content. Timely, applicable and targeted educational content will improve the results of ideological and political education work. Therefore, we should improve the comprehensiveness and timeliness of the educational content, not only within the scope of the fixed educational content of the conventional education and tax system, but also in the light of the current political and mainstream ideological development at home and abroad. Broaden the coverage of educational content, enrich educational themes, keep up with the pace of major national policies and the evolution of social values, and promptly spread the ideas advocated by the state and society to grass-roots tax officials, Always maintain the comprehensiveness, advanced nature and timeliness of the ideological and political education work of grass-roots tax officials.

\subsection{To Carry out Ideological and Political Education in a Wide Range of Ways and Depth}

Carry out ideological and political education through collective activities. In addition to the teaching and dissemination of ideological and political theory, carrying out ideological and political practice activities to enhance the personal feelings of the educated in a practical way is also an important way to carry out ideological and political education. For example, we can carry out party building in the form of team building, go deep into grass-roots level and cooperate with the masses, and so on, so as to give full play to the leading role of the party and strengthen the ties between cadres and the masses while going deep into the grass roots. To enhance the public's satisfaction and sense of trust in the contingent of cadres of the tax authorities; Secondly, it can be carried out through the infiltration of cultural activities, osmotic education as a way of self-education, in recent years, more and more ideological and political educators favor. As the grass-roots tax authorities can also carry out as many ideological and political and cultural activities as possible to carry out penetrating education, enhance the inner awareness of the educated object, so as to affect its behavior effect and improve the ideological and political level. For example, we can carry out visiting experience and visit the red education base to enhance the patriotic consciousness of grass-roots tax officials. To carry out the role exchange experience, grass-roots tax officials can exchange roles with taxpayers, and personally experience the inconvenience of taxpayers in handling tax-related matters, so as to improve the service consciousness of tax officials who are eager to serve taxpayers. The ideological and political education of the tax officials of the grass-roots tax authorities can be strengthened by means of incentives. First, praise the tax officials with high ideological and political level and excellent performance. Set up the "excellent tax list", regularly select outstanding tax officials who have outstanding performance in work, life or other aspects for public praise; For the unpositive phenomenon in the educational work, it is necessary to give some guidance to it, and the punishment will lead to the feeling of resistance to a certain extent. The purpose of the ideological and political education work is to strengthen the unified consciousness and strengthen the construction of work style. The purpose of holding advanced deeds report sessions, tour sessions, etc., to publicize the advanced ideological and political deeds of tax officials is to set an excellent example, to lead and influence the overall tax officials with advanced models, and to improve their ideological and political level. The second is to set up an incentive system to give appropriate rewards to tax officials with outstanding ideological and political levels. Through the principle of taxpayers' score and satisfaction, as well as the ideological and political assessment within the organization, for tax personnel who have achieved higher scores, grass-roots tax authorities can set up incentive funds according to their own management practice. The outstanding tax officials selected on a regular basis shall be given material 
rewards, and the vast number of tax officials shall be encouraged to be more progressive in the form of rewards.

\section{Conclusion}

Under the background of the new period, the tax departments should constantly adapt to the new characteristics of the new period, further broaden the scope of ideological and political education, innovate all kinds of forms, and promote the development of the work more effectively.

\section{References}

[1]. Vicente Navarro,A critique of the ideological and political positions of the Willy Brandt report and the WHO Alma ata declaration. Social science \& medicine vol.18 (2016) No.6 P467-74.

[2]. Wenya Chen, THE IDEOLOGICAL AND POLITICAL WORK---MOTIVATION APPROACHES TO MANAGEMENT IN CHINA, International Journal of Manpower, International Journal of Manpower, Vol 17 (2016) No.43, P335-43.

[3]. Xie Hong, Thinking on Promoting the Ideological and Political Construction of the Grassroots National Tax Department under the New Normal[J]. Taxation. 2017(34).

[4]. Liu Jing, Some Thoughts on Taxation from the Perspective of Ideological and Political Education [J]. Theoretical Observations. 2016(03).

[5]. Liu Xiao, He Mingyu, Thinking on Strengthening and Improving the Ideological and Political Work of Local Tax System[J]. Learning Monthly. 2012(08). 